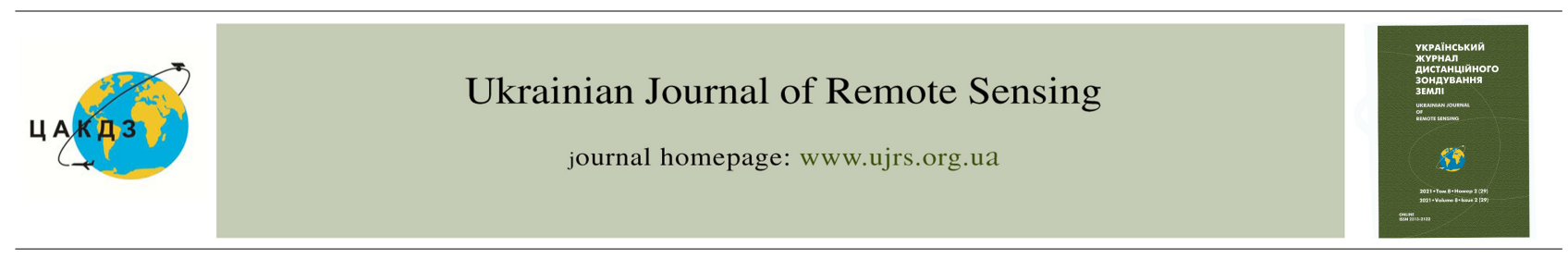

10.36023/ujrs.2021.8.2.192

UDC 528.8

\title{
A method of quasi-continuous image formation in observation devices with discrete receivers
}

\author{
M. Y. Slonov, O. O. Maryliv * \\ Military-Diplomatic Academy named after Eugene Bereznyak. 81 Yuriya Illenka str., Kyiv 04050, Ukraine
}

The article proposes a new method of quasi-continuous image formation in observation devices with discrete receivers. The increase in the number of spatial sampling points in the object image is provided by intraframe scanning. Scanning is carried out by a photosensitive matrix with a regularly changed (controlled) density of the elementary receivers (CDR-matrix). The CDR-matrix contains identical elementary receivers. They are regularly distributed over the matrix surface. The vertical and horizontal distance between adjacent receivers is a multiple of the size of the elementary receiver. The CDR-matrix becomes equivalent in pixel dimensions to a larger photosensitive matrix. The magnitude of the multiplicity placement of the receivers is chosen by the developer when designing the light-sensitive matrix. The image of the object by the CDR-matrix (a separate frame) is composed of a series of snapshots. Each snapshot is formed by signals coming from all elementary receivers of the CDR-matrix. The number of snapshots in the frame is set by the multiplicity of the size of the elementary receivers vertically and horizontally. While using intraframe scanning, the CDR-matrix with a pixel size of the video format can operate in the mode of a photosensitive matrix with a pixel size of 2.5 MP. A CDR-matrix with a pixel size of $6 \mathrm{MP}$ can operate as a $48 \mathrm{MP}$ matrix of a conventional design. A mechanism for storing a frame with observation results when using a CDR-matrix is proposed. It assumes the use of the matrix addition operation. The signal matrix of the observed frame is considered as the sum of the signal matrices of all the snapshots in the frame. Application of the developed method will make it possible to multiply the pixel size of the image relative to the pixel size of the controllable photosensitive matrix. The advantages of the proposed method also include the absence of a mandatory decrease in the effective area of an elementary receiver with an increase in their number in the photosensitive matrix; simplification of hardware measures to reduce the effect of image shift on its quality; absence of information losses in the intervals between adjacent elementary receivers.

Keywords: quasi-continuous image, intraframe scanning, photosensitive matrix, matrix elements

(C) M. Y. Slonov, O. O. Maryliv. 2021

\section{Materials and Methods}

The observation devices are designed to observe an object by its image. In them, the light-electric conversion is realized by means of discrete photosensitive matrix.

Images are usually perceived by the human eye in the form of unstructured spatial components of the object. At a high level of magnification it is possible to notice that the image of object details is composed of separate points (pixels).

The state of each pixel is determined by the state of the conjugate part of the object, which is characterized by the value $u_{j}$. Therefore, the appearance of the observed area $U$ can be regarded as the distribution of random quantities of a system $u_{j}$ in the space $\Omega$ (Krasilnikov, 2011):

$$
U=U\left\{u_{j}: u_{j} \in \Omega, j=(1, N)\right\},
$$

where $N$ is the number of pixels, which participate in the image construction of the observation area.

Aggregate of values uj are characterizing a spatial distribution of radiation energy (reflected or (and) generated) from details of

\footnotetext{
*E-mail: delavar65000@gmail.com

http://orcid.org/0000-0003-4269-2386

Tel: +380997372470
}

object in the direction of device view. The content of the observation area corresponds to the principle of casualty at any current moment. The image $X$ of an observation area (Fig. 1) can be considered as a function of probability distribution $P$ of values $x_{j}$ of its elements (Krasilnikov et al., 2002):

$$
X=X\left\{x_{j}: x_{j} \in \Omega, j=(1, N)\right\}=P\left\{x_{j}: x_{j} \in \Omega, j=(1, N)\right\}
$$

This approach is appropriate when we are identifying, analyzing and classifying typical landscapes based on the results of their observation.

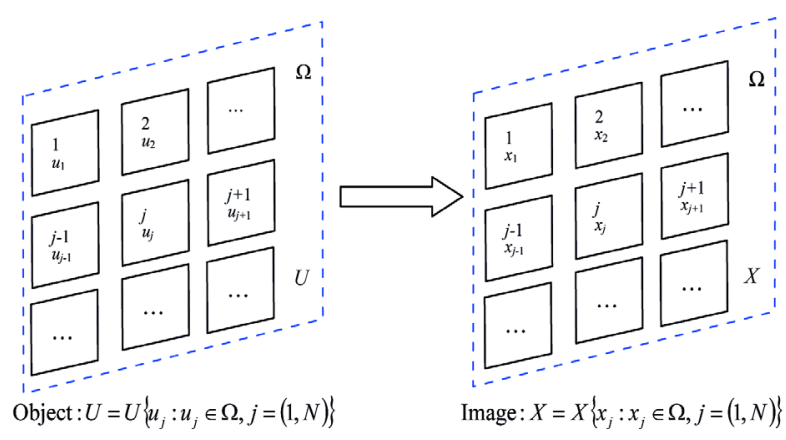

Fig. 1. Fields of an object and its image in space $\Omega$ 
In (2) the space $\Omega$ is limited by the angle of view of observation device. Elements $x_{j}$ are functionally related to values $u_{j}$ by energy calculation of the observation devices, taking into account its spatial transfer properties.

The result of the observation of an object is spatial information about its external structure (small details). As a consequence, the structure of the observation devices is always aimed at reproducing the smallest components of the object in the image (Mitchell, 1984). Such possibility can be achieved by using the receivers with the minimum spatial resolution.

The resolution of the observation devices is always limited. That is why the image in (2) is considered as a set of $X$ values of the parameter $x_{j}$ in the image nodes - elements of resolution. For digital image such nodes are separate pixels.

Discretization of an image into separate pixels will decrease of some spatial information about the object. First, within each resolution element the value of parameter $x_{j}$ is averaged. Information about the distribution of the values of the informative parameter $x_{j}$ is lost. If an individual pixel corresponds to space $\Delta \Omega_{j}$ the value of the parameter $x_{j}$ of the image $X$ is averaged within the pixel area to the value $\tilde{x}_{j}$ :

$$
X=X\left\{\tilde{x}_{j}: x_{j} \in \Omega, j=(1, N), \tilde{x}_{j}=\tilde{x}_{j}\left(\Delta \Omega_{j}\right) \rightarrow x_{j} \approx \tilde{x}_{j}\right\} .
$$

Within a single pixel the gradations of the image cannot be observed. As the value of $\Delta \Omega j$ increases, the number of spatial gradations of the informative parameter of the object is decreases.

Secondly, some details of the object image accounted for the gap $\Delta$ between two neighboring pixels. This part of the image is not involved in the light-electric transformation.

The design of the light-sensitive matrix provides for the reduction of such losses. Pixels are made as small as possible and placed as close together as possible. According to (3) the requirements for decrease information will be as follows:

$$
\Delta \Omega_{j} \rightarrow 0, \Delta \rightarrow 0, x_{j} \rightarrow \tilde{x}_{j}: j=(1, N) .
$$

Let's pay attention to one more peculiarity of observation devices. Both photo- and video- systems (both static and dynamic observation devices) work with separate images. Such images purchase specified iconic properties during exposure time - shutter speed $t_{e}$. While exposing, the value of $\tilde{x}_{j}$ (within $\Delta \Omega_{j}$ of each $j$-th pixel) is accumulated over the exposure time $t_{e}$ to the value $\tilde{x}_{j}$. In this form the object image is read or remembered as:

$$
X=X\left\{\tilde{x}_{t, j}: x_{j} \in \Omega, j=(1, N), \widetilde{x}_{j}=\tilde{x}_{j}\left(\Delta \Omega_{j}\right) \rightarrow x_{j} \approx \tilde{x}_{t, j}\right\} .
$$

If during the exposure time $t_{e}$ the relative position of the object and the observer's receiver will changes, so the values of $\tilde{x}_{t, j}$ will depend on the signal values at the neighboring pixels. This is the so-called image shift, which leads to image distortion.

The change in the relative position of object and receiver occurs in two cases. The first is when the object or (and) the observation device is functionally movable. The second case is unforced mobility due to unpredictable vibrations of: observer, observation device, its components and parts. Therefore we mast kept to a minimum the shutter speed for exposure.

For video devices the above remarks are also valid. In such devices, the discretization of the object image takes place not only in space, but also in time $t$. A dynamic area is observed due to viewing of a series of $M$ images in time $T$. Each $i$-th frame $X^{t}$ is exposed at the moment $t_{i}=T / i$. In this case, the image of the object is formalized as:

$$
X=\left\{X^{i}\right\}=\left\{X^{i}\left\{\tilde{x}_{t, j}^{i}: x_{j} \in \Omega, j=(1, N), \tilde{x}_{j}=\tilde{x}_{j}\left(\Delta \Omega_{j}\right) \rightarrow x_{j} \approx \tilde{x}_{t, j}\right\}, i=(1, M)\right\}
$$

Each $i$-th frame of the video can be described as follows:

$$
X^{i}=X^{i}\left\{\tilde{x}_{t, j}^{i}: x_{j} \in \Omega, j=(1, N), \tilde{x}_{j}=\tilde{x}_{j}\left(\Delta \Omega_{j}\right) \rightarrow x_{j} \approx \tilde{x}_{t, j}\right\}
$$

Discretization in time, i.e. the limited frame rate of the video, presupposes losing of information about the state of the object. This refers to the time intervals between two consecutive frames of the video. When choosing such an interval, one is guided by the physiological properties of the human eye or the level of dynamism of the area. In the first case, the limiting factor is the constancy of the human eye. In the sense it is its time resolution. If a single frame of the video is distorted, than the perception of the entire video changes in a certain way.

The presence of spatial and time discretization of the image leads to losing of some information about the object. Spatial discretization excludes the possibility of documenting the details between adjacent pixels and within an individual pixel. The time discretization excludes from the image analysis the details of the area that have changed between the $i$-th and $(i+1)$-th frames.

Let us limit our analysis by static (photographic devices) systems. Conditions (4) can be partially detailed. Spatial discretization of area $\Omega$ in observation devices occurs by constructing a receiver in the form of a matrix. Its pixel size is determined by rectangular placement of $m$ rows of elementary receivers with $n$ elementary receivers in each. In this case:

$$
\Omega=\left\{\Delta \Omega_{j}\right\}, j=(1, m \times n) .
$$

Minimization of the value $\Delta \Omega j$ will correspond to the maximum possible increase in the number of elementary receivers. According to $(4,5)$ the conditions of minimum spatial losses will be:

$$
(m \times n) \rightarrow \infty, \Delta \rightarrow 0, x_{j} \rightarrow \tilde{x}_{j}: j=(1, N) .
$$

This is the requirement for spatial discretization. While is documenting the results of observing of the object, there is also a time discretization. It is a consequence of image exposure during photo- and video- recording. Time discretization will be minimal at maximum possible light sensitivity of the receiver (Mitchell, 1984).

Thus, successful observation presupposes a non-structure receiver with infinitely high light sensitivity. It is physically impossible to realize such a receiver. There are several known ways to partially solve the problem of limited spatial resolution. They include the following hardware and algorithmic directions: - structural improvements (Popov et al., 2015; Popov, 2018), application of multicamera photographic devices (The largest, 2021) (but they complicate the observation device design);

- reduction of elementary receiver size to the diffraction limit while is increasing of number of such receivers in a photosensitive matrix (OWC, 2021; Rehm, 2021) (unfortunately, their realization is technologically difficult and they are limited by theoretical limits of applicability);

- taking into account in the design of the receiver tasks for the observation of objects with a finite size of object recognition 
(Korobchynskyi et al., 2020) (but it is not always possible to predict in advance the required depth of object recognition by its image);

- using the features of zonal images of the object and its components (Popov et al., 2007; Ferraris et al., 2018) (at hyperspectral observation of the object is accumulated a huge amount of information, its interpretation requires high and specific qualification of the operator);

- application of neural network technologies, algorithms of extrapolation, interpolation, probabilistic analysis and estimation (Kwan, 2018; Stankevich et al., 2020) (it is a very promising areas, which are based on the use of a priori information like the results of observation and documentation of the observation device).

It can be argued that the problem of increasing the number of spatial discretization elements in the image of observation device is currently not completely solved. The aim of the research is to obtain a quasi-continuous image of observation device with discrete receivers. This aim is achieved by developing a method of obtaining such an image. Increasing the number of elements of spatial discretization in the image is provided by intraframe scanning. In this case, the pixel size of the image significantly exceeds the pixel size of the photosensitive matrix. Requirements to the pixel size of the matrix are decreased, hardware measures for image shift compensation are simplified and the distance between individual neighboring pixels is absent.

\section{Results and Analysis}

The method is based on element-by-element scanning of the image. Scanning is carried out by a photosensitive matrix with a regularly changed (controlled) density of elementary receivers (CDR-matrix). A snapshot what is taken during scanning after each displacement of the optical image relative to the photosensitive matrix by one pixel. The number of $K$ displacements (accordingly the number of snapshots) is set in a way, which all elements of sampling of the observation area are scanned. The essence of it is next. The same elementary receivers of size $d$ are placed in the CDR-matrix. They are distributed in a regular way on the surface of the matrix. The distance between neighboring receivers is $k d$. The value $k$ specifies the multiplicity of placement of size $d$ in the distance between two adjacent elementary receivers by vertically and horizontally. Fig. 2 shows an example of a section of CDR-matrix. Its horizontal placement multiplicity is $k_{1}$ and its vertical placement multiplicity is $k_{2}$. The value of the placement multiplicity is selected by the developer during design of the photosensitive matrix. The initial data are the requirements for image sampling and the physical possibility of their realization in the given design.
Image of the object by the CDR-matrix (separate frame) is composed of a series of snapshots. Each snapshot is formed by signals coming from all elementary receivers of the CDR-matrix. The number of snapshots in the frame is set by multiplicity of placement of size $d$ by vertically and horizontally.

The first snapshot $X_{1}$ of the frame can be formalized by (3) taking into account (5):

$X_{1}=X_{1}\left\{\tilde{x}_{1, j}: x_{1, j} \in \Omega, j=(1, m \times n), \widetilde{x}_{1, j}=\widetilde{x}_{1, j}\left(\Delta \Omega_{1, j}\right) \rightarrow x_{1, j} \approx \widetilde{x}_{1, j}\right\}$.

In (7) $m$ and $n$ are the number of elementary receivers by horizontally and vertically of CDR-matrix. Subsequent $r$-th snapshots are formed similarly, but each time after displacement of image (or matrix) by one pixel. The shift is made in the direction of vertical or horizontal row of receivers. It is the displacement that ensures the documentation within the whole observed area.

Formalizing the frame of the total digital image $X$ will be:

$$
\begin{gathered}
X=\left\{X_{r}\right\}=\sum_{r=1}^{r=K} X_{r}, \\
X_{r}=X_{r}\left\{\tilde{x}_{r, j}: x_{r, j} \in \Omega, j=(1, m \times n), r=(1, K), K=\max _{0 \leq r \leq K} r, \widetilde{x}_{r, j} \rightarrow x_{r, j}\right\} .
\end{gathered}
$$

In $(8,9), K$ means the number of snapshots, which is contained in one frame. Compared to $(3)$, in $(7,9)$ the symbol "approximately equal" $(\approx)$ is replaced by the symbol "tends to" $(\rightarrow)$. The validity of this substitution is explained by two factors. An individual pixel may have an arbitrarily small size within physical feasibility. The inter-pixel gap $\Delta$ between two neighboring pixels is decreased to zero. The image becomes quasi-continuous.

Examples of the sequence of frame formation are considered in Fig. 3. In Fig. 3 a shows schematically a section of CDR-matrix with $k_{1}=2, k_{2}=0$. In Fig. 3 a, the multiplicities of elementary receiver placement are $k_{1}=2, k_{2}=1$. Blue pixels characterize the density of placement of elementary receivers in the CDR-matrix.

In this case the frame includes 3 snapshots for Fig. 3 a and 6 snapshots for Fig. 3 b. At time $t=0$ the first snapshot is exposed. The image in it consists of the signals from the elementary receivers $d$, in Fig. 3 (blue color). This is the first component (snapshot 1) $X_{1}$ of frame $X$. The second snapshot $X_{2}$ is taken when the image or matrix is moved horizontally by the amount $\mathrm{d}$ along the line of elementary receivers (Fig. 4). The elementary receivers will take position 2, as shown in Fig. 3. A snapshot $X_{3}$ is taken when the elementary receivers will be at position 3 .

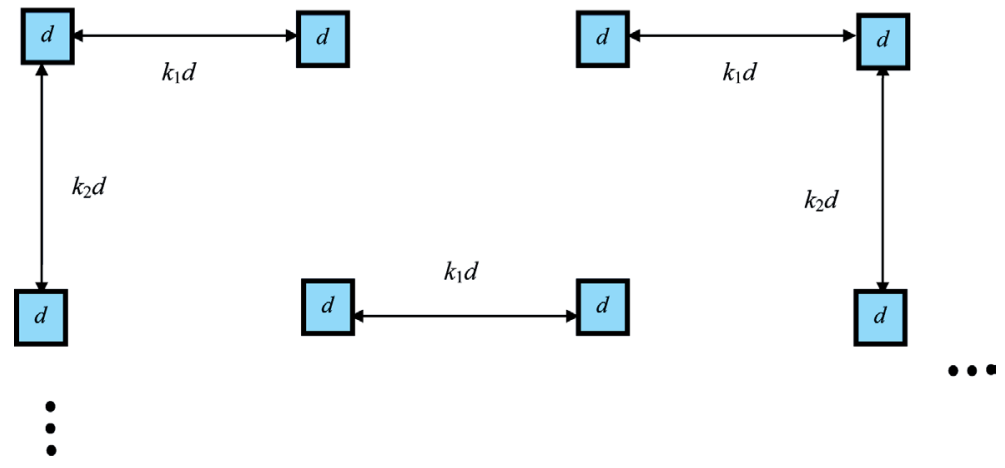

Fig. 2. Structure of a matrix with a regularly changed (controlled) density of elementary receivers (CDR-matrix) 


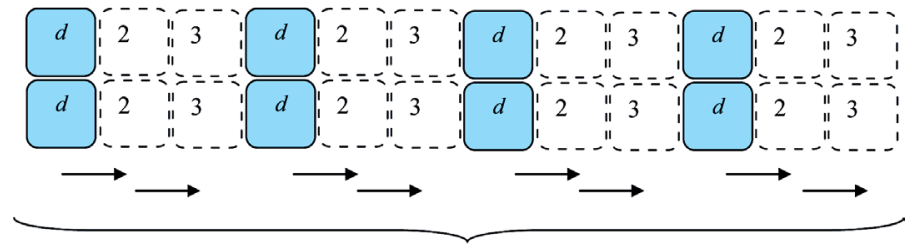

One frame. $K=3$

a

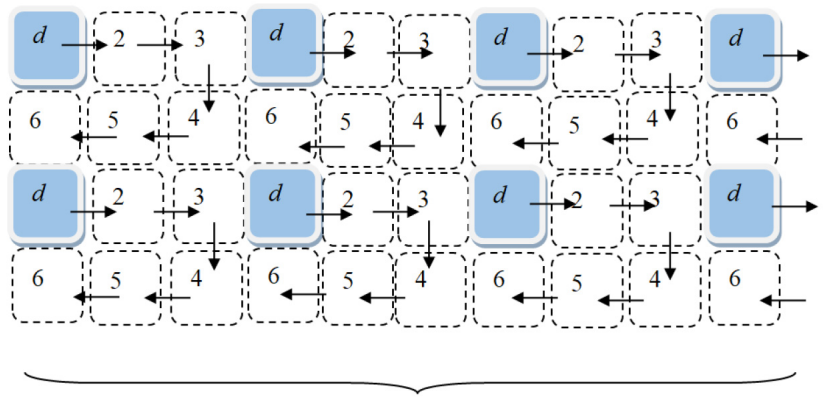

One frame, $K=6$

b

Fig. 3. Formation of a frame by CDR-matrix: $\mathbf{a}-k_{1}=2, k_{2}=0, K=3 ; \mathbf{b}-k_{1}=2, k_{2}=1, K=6$

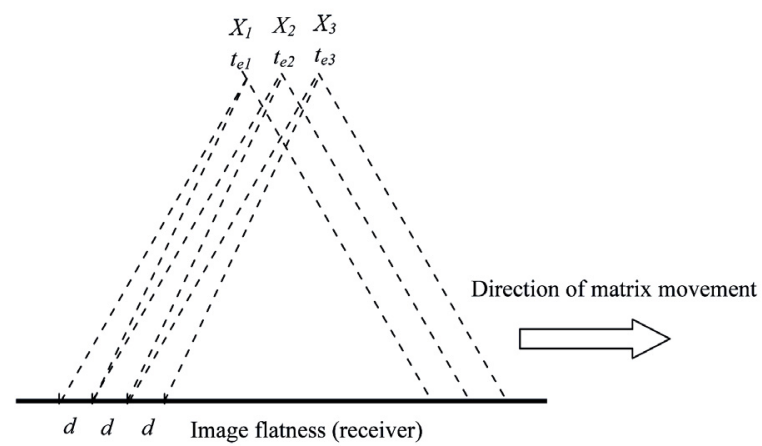

Fig. 4. Generation of snapshots $X_{1}, X_{2}, X_{3}$

For Fig. 3 b the formation of the frame is completed by snapshots $4,5,6$. The scanning continues in the direction of the arrows after shifting the scanning line to the size $d$ of one pixel.

The final image of the object is constructed by adding all snapshots of the frame to each other. According to (10), for Fig. 3 a the frame $X$ consists of three snapshots:

$$
X=\left\{X_{r}\right\}=\sum_{r=1}^{r=3} X_{r}=X_{1}+X_{2}+X_{3}
$$

In the general case, according to (11), the image in the frame is formalized as:

$X_{r}=X_{r}\left\{\tilde{x}_{r, j}: j \in(1, K \times m \times n), r=(1, K), K=\left(1+k_{1}\right)\left(1+k_{2}\right), \tilde{x}_{t, j} \rightarrow x_{1, j}\right\}$

or:

$X_{r}=X_{r}\left\{\tilde{x}_{r, j}: j \in(1, K \times m \times n), r=(1, K), K=\max _{1 \leq r \leq\left(1+k_{1}\right)\left(1+k_{2}\right)} r\right\}$

The hardware implementation of this method involves solving two problems. The first one is to create a photosensitive matrix of size $(m \times n)$ with a regularly changed (controllable) density of elementary receivers (CDR-matrix).

The density of the distribution of elementary receivers is determined by the distance between adjacent elementary receivers by horizontally and vertically. They must be multiples of the size of the elementary receiver $d$. Thus, the values of multiplicity coefficients $k_{1}$ and $k_{2}$ are laid down. The CDR-matrix becomes equivalent in pixel dimensions to a light-sensitive matrix of size $\left(m_{\mathrm{z}} \times n_{\mathrm{z}}\right)$.

$$
m_{\Sigma} \times n_{\Sigma}=(m \times n) K=(m \times n)\left[\left(k_{1}+1\right)\left(k_{2}+1\right)\right] .
$$

The results of calculations according to (14) are presented in Table 1 . The $640 \times 480$ video standard was considered as the initial pixel size of the CDR-matrix.

Table 2 will also be interesting for the analysis. It shows the results of calculations for CDR-matrix with different pixel size.

The data, which are presented in Table 1 and Table 2, are visualized in Fig. 5. Due to intraframe scanning, the CDR-matrix with pixel size of video format can work in the mode of photosensitive matrix with pixel size of 2.5 MP. In CDR-matrix with a pixel size of $6 \mathrm{MP}$ can operate as a $48 \mathrm{MP}$ matrix of conventional design. 
Table 1.

Physical and virtual pixel size of CDR-matrix for video format

\begin{tabular}{|c|c|c|c|c|}
\hline $\begin{array}{l}\text { Number of pixels by } \\
\text { horizontally, } m\end{array}$ & $\begin{array}{l}\text { Number of pixels } \\
\text { by vertically, } n\end{array}$ & $\begin{array}{l}\text { Number of } \\
\text { snapshots per } \\
\text { frame, } K\end{array}$ & $\begin{array}{l}\text { Pixel size of the } \\
\text { CDR-matrix, } m \times n, \mathrm{MP}\end{array}$ & $\begin{array}{l}\text { Virtual pixel size of the } \\
\text { equivalent matrix, } \\
m_{\Sigma} \times n_{\Sigma}, \mathrm{MP}\end{array}$ \\
\hline 640 & 480 & 1 & 0.31 & 0.31 \\
\hline 640 & 480 & 2 & 0.31 & 0.62 \\
\hline 640 & 480 & 3 & 0.31 & 0.93 \\
\hline 640 & 480 & 4 & 0.31 & 1.24 \\
\hline 640 & 480 & 6 & 0.31 & 1.86 \\
\hline 640 & 480 & 8 & 0.31 & 2.48 \\
\hline
\end{tabular}

Table 2.

Physical and virtual pixel size of the CDR-matrix

\begin{tabular}{|c|c|c|c|c|c|c|}
\hline \multirow{2}{*}{$\begin{array}{l}\text { Pixel size of the CDR- } \\
\text { matrix, } m \times n, \mathrm{MP}\end{array}$} & \multicolumn{6}{|c|}{ Virtual pixel size of the equivalent matrix, $m_{\Sigma} \times n_{\Sigma}$, MP, at $K$} \\
\hline & 1 & 2 & 3 & 4 & 6 & 8 \\
\hline 0.31 & 0.31 & 0.62 & 0.93 & 1.24 & 1.86 & 2.48 \\
\hline 1.0 & 1.0 & 2.00 & 3.00 & 4.00 & 6.00 & 8.0 \\
\hline 2.0 & 2.0 & 4.00 & 6.00 & 8.00 & 12.0 & 16.0 \\
\hline 3.0 & 3.0 & 6.00 & 9.00 & 12.00 & 18.0 & 24.0 \\
\hline 4.0 & 4.0 & 8.00 & 12.00 & 16.00 & 24.0 & 36.0 \\
\hline 6.0 & 6.0 & 12.00 & 18.00 & 24.00 & 36.0 & 48.0 \\
\hline
\end{tabular}

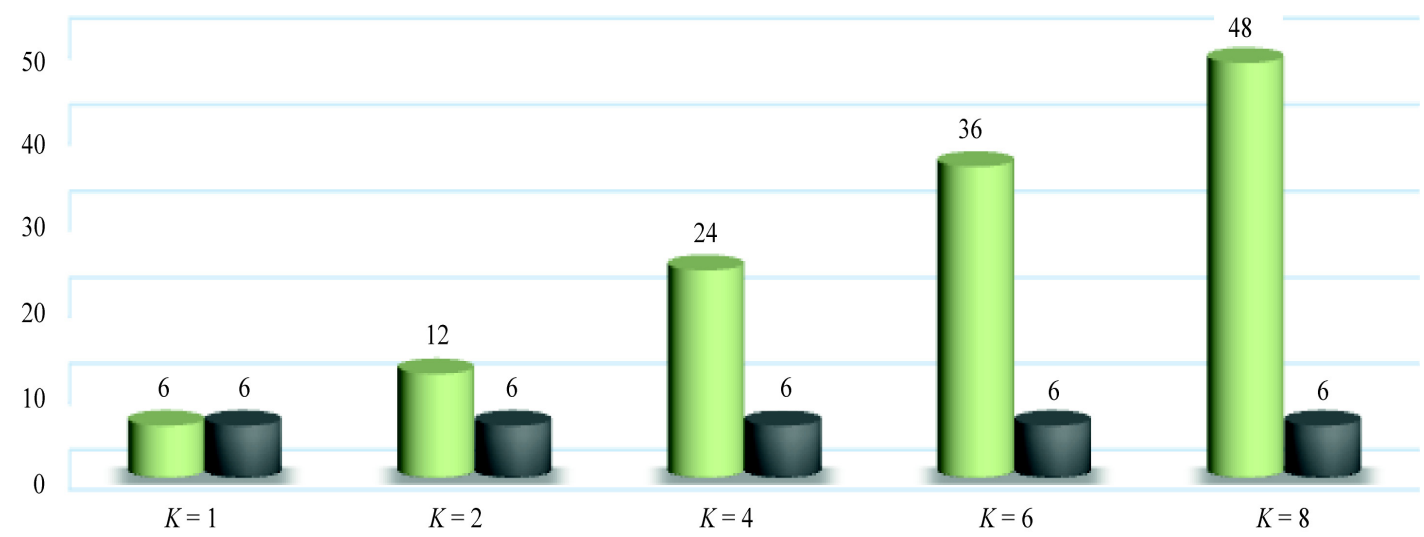

Fig. 5. Pixel size of the image in the observation device with 6 MP CDR-matrix: row 1 is with modified density level; row 2 is conventional matrix

By increasing the value $K$ and decreasing the pixel size, you can achieve any pixel size of the image. In this case, it goes from a discrete form to almost continuous (quasi-continuous).

Decreasing the pixel size of the photosensitive matrix will increase the effective area of each elementary receiver. Due to this, it is possible to decreasing the influence of spatial noise on image quality. This will increase the light range of the observation device (Korobchynskyi et al., 2021).

The second task is to change the mechanism of saving a frame with the results of observation. Such a frame consists of $K$ snapshots. Each snapshot contains $(m \times n)$ values of signals from elementary receivers. All snapshots do not contain repeating pixels. According to the conditions of elementary receiver's distribution in the CDR-matrix, equation (10) can be considered as a matrix. In this case, the frame matrix is memorized as a matrix sum of all snapshots of the frame. That is the elements of the frame are all significant elements of all snapshots. All pixels of the frame (image in frame) are the elements of the matrix of this mode:

$$
X_{r}=\left[\begin{array}{ccc}
x_{11} & \cdots & x_{1 m} \\
\vdots & \ddots & \vdots \\
x_{n 1} & \cdots & x_{n m}
\end{array}\right],
$$

where $x_{n m}$ is the signal from the elementary receiver located in the $n$-th row and the $m$-th column.

The frame with the observation area is formed from $K$ snapshots in such a way that from the pixel size of the image in $(m \times n)$ it is necessary to go to the pixel size $K \times(m \times n)$ of the frame. Then we will write (10) in matrix form:

$$
X=\sum_{r=1}^{r=K} X_{r}
$$

where $X$ and $X_{1}$ matrix should have the same order horizontally and vertically.

In this case, it should correspond to the format of a frame $\left(m_{z} \times n_{z}\right)$ instead of a snapshot memory. At the pixel size of the 
CDR-matrix $(m \times n)$ the following relation determines the $m_{z}$ and $n_{\mathrm{z}}$ values:

$$
m_{\Sigma} \times n_{\Sigma}=m\left(k_{1}+1\right) \times n\left(k_{2}+1\right)
$$

The size of the matrix of signals of each of the snapshots must be the same. All matrix elements are columns and rows, which are not involved in this snapshot in the information extraction, will be zero. The matrix of signals from elementary receivers in the CDR-matrix with $k_{1}=2, k_{2}=0, K=3$ (see Fig. 3 a) will take the form that is shown in Fig. $6 \mathrm{a}-\mathrm{c}$. Each matrix is memorized by the system of signals from elementary receivers and augmented with zero columns and (or) rows. Such additions correspond to the signals about the areas of the observed area, which have already been viewed.

The matrix of signals from all snapshots (the equivalent frame matrix) is the result of summing the matrix of all snapshots (see Fig. 6 d). There are no zero columns or rows in it. All its components are elements of signal matrices of all individual snapshots of the frame. In this case, is saved the data about geometrical location of image elements. optical snapshot, CDR-matrix must move relative to each other. In this case all parts (pixels) of the image pass over the surface of elementary receivers. During the movement is taken a series of snapshots. Thirdly, each snapshot is exposed separately after moving the image relative to the CDR-matrix by one pixel. Pixelby-pixel displacement is implemented in the surveillance tools in the image shift compensation system. It is only necessary to refine the law of change of image displacement rate (Korobchynskyi et al., 2021).

Questions arise about the possibility of physical implementation of photography with the CDR-matrix. First of all it concerns time constraints. Each separate frame is formed by summing up $K$ snapshots. Each of them is exposed separately with a shutter speed of $t_{e}$. The exposure time of a frame will be $\left(K \times t_{e}\right)$. If we take into account the time of image movement tm per pixel $(2 \ldots 8 \mu \mathrm{m})$ between two consecutive snapshots, the time $t_{k}$ for frame formation will be:

$$
t_{k}=\left(k_{1}+k_{2}+2\right)\left(t_{e}+t_{m}\right)=K\left(t_{e}+t_{m}\right)
$$

The standard average shutter speed in the camera is $0.01 \mathrm{~s}$.

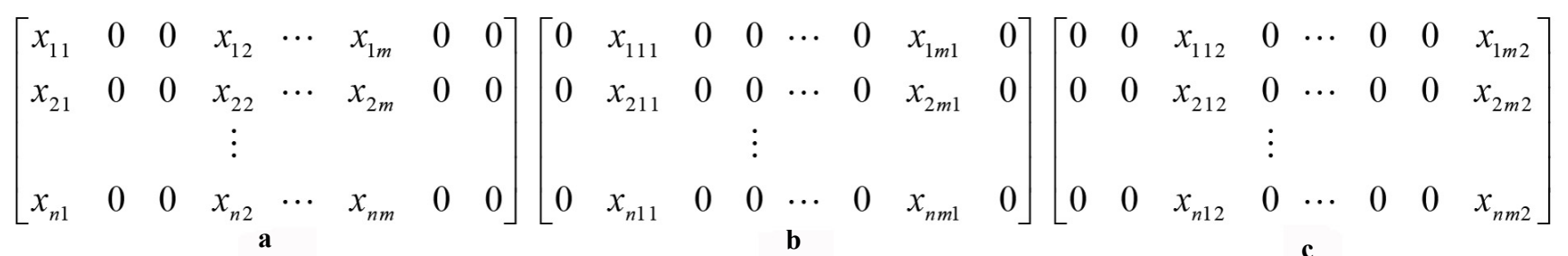

$$
\begin{aligned}
& {\left[\begin{array}{cccccccc}
x_{11} & x_{111} & x_{112} & x_{12} & \cdots & x_{1 m} & x_{1 m 1} & x_{1 m 2} \\
x_{21} & x_{221} & x_{222} & x_{22} & \cdots & x_{2 m} & x_{2 m 1} & x_{2 m 2} \\
& & & \vdots & & & & \\
x_{n 1} & x_{n 11} & x_{n 12} & x_{n 2} & \cdots & x_{n m} & x_{n m 1} & x_{n m 2}
\end{array}\right]}
\end{aligned}
$$

Fig. 6. The matrix of signals from elementary receivers: $\mathbf{a}$ - the matrix of signals of the first snapshot, $\mathbf{b}$ - the matrix of signals of the second snapshot, $\mathbf{c}-$ the matrix of signals of the third snapshot, $\mathbf{d}-$ equivalent frame matrix

The sequence of remembering pixels in the digital image will be:

$$
j=\left(j_{1}, j_{2}, j_{3}\right), j \in(1, K \times m \times n) .
$$

where $j_{1}, j_{2}, j_{3}$ are the serial number of pixels in the first, second and third snapshot, respectively; $j$ is the serial number of the pixel in the frame.

Thus, when forming a digital image of a frame according to $(12,13)$, at the beginning the first pixels of all snapshots of the frame are memorized, then all the second, third and so on. It is obligatory to observe the sequence of pixels, which are memorized, both by numbers of elementary receivers and by numbers of snapshots.

The formation of the frame in this case has a number of features. Firstly, the frame, that is the image of the observed area, is the result of the addition of a certain number snapshots. The pixel composition of the snapshots does not overlap with each other. The total sum of pixels of all images is equal to the number of pixels of the frame. Secondly, during the frame formation the
Time tm can be considered close to this value. Then up to 10 frames are formed in one second at minimum sensitivity. At medium sensitivity, it is already several dozens of frames. Such frame rate will allow making not only image but also video recording.

Almost all modern cameras have a mechanism of image shift compensation. Such mechanism is made by mechanical, optical or electronic scheme. By functional purpose, time and spatial ranges of work it is similar to devices of photography by using CDR-matrix (Korobchynskyi et al., 2020).

There are physical limitations to the possibilities of observation using a CDR-matrix. They include:

- the minimum possible or structurally feasible physical dimensions of an individual pixel (elementary receiver);

- minimum possible or reasonable density of positioning of elementary receivers of a light-sensitive matrix by energy and hardware features of an observation device;

- accuracy possibilities of realization of necessary trajectory of image scanning. 


\section{Conclusions}

The article proposes a method of quasi-continuous image formation in observation devices with discrete receivers. The method involves the use of a light-sensitive matrix with a regularly changed (controlled) density of elementary receivers (CDR-matrix). Application of the developed method will allow multiplying the pixel size of the image relative to the pixel size of the controlled photosensitive matrix. The advantages of the proposed method include:

- decreased requirements for the pixel size of the matrix;

- no obligatory decreased of the effective area of the elementary receiver when increasing their number in the light-sensitive matrix;

- simplification of hardware measures to decreased the effect of image shift on its quality;

- absence of information losses on gaps between adjacent elementary receivers.

\section{References}

Ferraris, V., Dobigeon, N., Wei, Q., Chabert, M. (2018). Detecting changes between optical images of different spatial and spectral resolutions: a fusion-based approach. IEEE transactions on geoscience and remote sensing, 56, 1566-1578. https://doi.org / $10.1109 /$ tgrs.2017.276534

Korobchynskyi, M., Slonov, M., Rudenko, M., Maryliv, O. (2020). Assessment of the effect of image shift on the results of photo-video recording. Proceedings of the IEEE 40th International Conference on Electronics and Nanotechnology, 641-645. https://doi.org / 10.1109/elnano50318.2020.9088766.

Korobchynskyi, M., Slonov, M., Rudenko, M., Maryliv, O., Pylypchuk, V. (2021). Critical modes of photography: light sensitivity and resolution. Communications in Computer and Information Science, 1158, 264-274. https://doi.org/10.1007/978-3-030-61656-4.
Krasilnikov, N. N. (2011). Digital Processing of 2D and 3D Images. BHV. (in Russian).

Krasilnikov, N. N., Krasilnikova, O. I. (2002). Study of the efficiency of the human visual system in recognizing static images. Journal of Optical Technology, 69, 397-403.

Kwan, C. (2018). Image resolution enhancement for remote sensing applications. ICVISP 2018: Proceedings of the 2nd International Conference on Vision, Image and Signal Processing, 1-5. https:// doi.org/10.1145/3271553.3271590.

Mitchell, E. N. (1984). Photographic Science. John Wiley \& Sons.

OWC Unleashes 2nd Gen ThunderBlade SSD Drives With a Top Speed of 5000 MBps. (2021). Retrieved from: https://www.dpreview.com/ news/2707357090.

Pat. 81195 UA, IPC G06K 9/00, G06K 9/46, G06K 9/62, G06K 9/80, Method for enhancing spectral variability of lagospectral aerospace images, Popov, M. O., Stankevich, S. A., Kozlova, A. O., Publ. 10.12.2007. (in Ukrainian).

Popov, M. A. (2018). On the technology of creating new technologies in remote sensing. Ukrainskyj zhurnal dystancijnogo zonduvannja Zemli,17, 4-9. (in Russian).

Popov, M. A., Stankevich, S. A., Shklyar, S. V. (2015). Algorithm for enhancing the distributional efficiency of images displaced by subpixels. Mathematical Machines and Systems, 1, 29-36. (in Russian).

Rehm, L. (2021). Samsung Launches 1/3.4" 20 MP Sensors for Use in Smartphone Front Cameras and Telemodules. Retrieved from: https:/ /www.dpreview.com/news/5407916317.

Stankevich, S. A., Maslenko, O. V., Andronov, V. V. (2020). Neural network technology adaptation to the small-size objects identification in satellite images of insufficient resolution within the graphic reference images database. Scientific Centre for Aerospace Research of the Earth, National Academy of Sciences of Ukraine, 27, 13-17. (in Ukrainian).

The largest digital camera in the world has a resolution of 3.2 gigapixels. (2021). Retrieved from: https://tehnobzor.ru/stati/samaja-bolshajakamera. (in Russian).

\section{МЕТОД ФОРМИРОВАНИЯ КВАЗИНЕПРЕРЫВНОГО ИЗОБРАЖЕНИЯ В ВИДОВЫХ СРЕДСТВАХ С ДИСКРЕТНЫМИ ПРИЕМНИКАМИ} М. Ю. Слонов, А. А. Марылив

Военно-дипломатическая академия имени Евгения Березняка, ул. Юрия Ильенко 81, Киев 04050, Украина

В статье предложен новый способ формирования квазинепрерывного изображения в видовых средствах с дискретными приемниками. Увеличение количества элементов пространственной дискретизации в изображении объекта обеспечивается внутрикадровым сканированием. Сканирование осуществляется светочувствительной матрицей с закономерно изменённой (управляемой) плотностью размещения элементарных приемников (УРЭП-матрица). В УРЭП-матрице размещены одинаковые элементарные приемники. Они закономерно распределены по поверхности матрицы. Расстояние между соседними приемниками по вертикали и горизонтали кратно размеру элементарного приемника. Закономерно изменённая (управляемая) плотностью размещения элементарных приемников матрица становится эквивалентной по пиксельным размерам светочувствительной матрице большего размера. Величина кратности размещения приемников выбирается разработчиком при конструировании светочувствительной матрицы. Изображение объекта УРЭП-матрицей (отдельный кадр) составляется из серии снимков. Каждый снимок формируется сигналами, поступающими от всех элементарных приемников УРЭП-матрицы. Количество снимков в кадре задаётся кратностью размещения размера элементарных приемников по вертикали и горизонтали. Благодаря внутрикадровому сканированию УРЭП-матрица с пиксельным размером видео формата может работать в режиме светочувствительной матрицы 3 пиксельным размером 2,5 Мпк. УРЭП-матрица с пиксельным размером 6 Мпк может работать как 48 Мпк матрица обычной конструкции. Предложен механизм сохранения кадра с результатами наблюдения при использовании УРЭП-матрицы. Он предполагает использование операции матричного сложения. Матрица сигналов наблюдаемого кадра рассматривается как сумма матриц сигналов всех снимков кадра. Применение разработанного способа позволит кратно увеличить пиксельный размер изображения относительно пиксельного размера управляемой светочувствительной матрицы. К преимуществам предложенного способа относятся также отсутствие обязательного уменьшения эффективной площади элементарного приёмника при увеличении их количества в светочувствительной матрице; упрощение аппаратных мер по уменьшению влияния сдвига изображения на его качество; отсутствие информационных потерь на промежутках между соседними элементарными приёмниками.

Ключевые слова: квазинепрерывное изображение, внутреннее сканирование, светочувствительная матрица, элементы матрицы

\section{МЕТОД ФОРМУВАННЯ КВАЗІБЕЗПЕРЕРВНОГО ЗОБРАЖЕННЯ У ВИДОВИХ ЗАСОБАХ З ДИСКРЕТНИМИ ПРИЙМАЧАМИ}

М. Ю. Слонов, О. О. Марилів

Воєнно-дипломатична академія імені Євгенія Березняка, вул. Юрія Іллєнка 81, Київ 04050, Україна

В статті запропонований новий метод формування квазібезперервного зображення у видових засобах спостереження 3 дискретними приймачами. Збільшення кількості елементів просторової дискретизації в зображенні об'єкта забезпечується внутрішньо кадровим скануванням. Сканування відбувається за допомогою світлочутливої матриці з закономірно змінною (керованою) частотою розміщення 
елементарних приймачів (КРЕП-матриця). У КРЕП-мариці розміщенні однакові елементарні приймачі. Вони закономірно розподілені по поверхні матриці. Відстань між сусідніми приймачами по вертикалі і горизонталі кратне розміру елементарного приймача. Закономірно змінна (керована) частотою розміщення елементарних приймачів матриця стає еквівалентною по піксельному розміру світлочутливій матриці більшого розміру. Величина кратності розміщення приймачів обирається розробником під час виготовлення світлочутливої матриці. Зображення об’єкта КРЕП-мариці (окремий кадр) складається із= серії знімків. Кожний знімок формується сигналами, що поступають від всіх елементарних приймачів КРЕП-мариці. Кількість знімків з піксельним розміром відео формату може працювати в режимі світлочутливої матриці з піксельним розміром 2,5 Мпк. КРЕП-мариця з піксельним розміром 6 Мпк може працювати як 48 Мпк матриця звичайної конструкції. Запропоновано механізм збереження кадру з результатами спостереження при використанні КРЕП-мариці. Від передбачає використання операцій матричного складання. Матриця сигналів кадру, що спостерігається, розглядається як сума матриць сигналів всіх знімків кадру. Використання розробленого методу дозволить кратно збільшити піксельний розмір зображення відносно піксельного розміру керованої світлочутливої матриці. До переваг запропонованого методу відноситься також відсутність обов'язкового зменшення ефективної площі елементарного приймачі при збільшенні їх кількості в світлочутливій матриці; спрощення апаратних вимог до зменшення впливу здвигу зображення на його якість; відсутність інформаційних втрат на проміжках між сусідніми елементарними приймачами.

Ключові слова: квазібезперервне зображення, внутрішнє сканування, світлочутлива матриця, елементи матриці

Рукопис статті отримано 24.03.2021 